\title{
IAMJ
}

INTERNATIONAL

AYURVEDIC

MEDICAL JOURNAL

(क) $\partial 0$

Research Article

ISSN: 2320-5091

Impact Factor: 6.719

\section{EFFICACY EVALUATION OF EXTRACTS OF BRASSICA JUNCEA AND BRASSICA ALBA SEEDS AS POTENTIAL ANTIBACTERIAL AGENT-IN VITRO STUDY, AGAINST PYOGENIC MICROBES - STREPTOCOCCUS PYROGENS, STAPHYLOCOCCUS AUREUS AND E.COLI}

\author{
Seema Nishant Parma ${ }^{1}$, Madhusudan N Pawar ${ }^{2}$, M. K. Rehman ${ }^{3}$, Madhuri Wagh ${ }^{4}$ \\ ${ }^{1}$ Associate Professor, Jupiter Ayurved Medical College, Shankarpur, Nagpur, Maharashtra, India \\ ${ }^{2}$ Retired Prof, and H.O.D., Department of Dravyaguna Vigyan, R. A. Podar Govt Ayurved Medical College, \\ Worli, Mumbai-18, Maharashtra, India \\ ${ }^{3}$ Retired Prof, and H.O.D., Department of Dravyaguna Vigyan, R. A. Podar Govt Ayurved Medical College, \\ Worli, Mumbai-18, Maharashtra, India \\ ${ }^{4}$ Associate Prof, Department of Dravyaguna Vigyan Govt. Ayurved College, Nagpur, Maharashtra, India
}

Corresponding Author: drseemaparma@gmail.com

https://doi.org/10.46607/iamj0409072021

(Published Online: July 2021)

Open Access

(C) International Ayurvedic Medical Journal, India 2021

Article Received: 17/06//2021 - Peer Reviewed: 24/06/2021 - Accepted for Publication: 25/06/2021

\begin{abstract}
The World Health Organization (WHO) reported that about $80 \%$ of the world's population depends primarily on traditional medicine. ${ }^{[1]}$ Ayurveda is the science of life, which aims at building a healthy body with a sound mind. During the past few decades, and in recent Covid-19 Pandaemic situations traditional systems of medicines have become a topic of global importance. The number of emerging multidrug-resistant microbial strains is continuously increasing and has become one of the most serious threats to the successful treatment of infectious diseases. In this study, the antibacterial potentials of the extracts of water, Petroleum ether, methanol \& Chloroform of Brassica juncea \& Brassica alba seeds were tested against mentioned pyogenic bacteria. Given reports of Brassica species in the treatment of various infections since the Vedic period \& Ayurveda, the seed oil had been investigated for its anti-microbial activity by several research workers. Some herbs from Rakshoghna Gana ${ }^{[2]}$ were screened for their in vitro anti-microbial activity on E.Coli and Staphylococcus Aureus. Hence as a part of further research, Brassica
\end{abstract}


juncea and Brassica alba various extracts and crude oils were evaluated for antibacterial activity against pyogenic bacteria Streptococcus aureus, Staphylococcus aureus and E.Coli by Agar Cup Dilution Technique against standard chemotherapeutic agents, by using 12 antibiotics, sensitivity discs. In vitro study revealed out that crude oil of Brassica juncea and Brassica alba is not potent as standard antimicrobial agents, but water extract and methanol extract possess significant antimicrobial activity in Vitro. Both the extract possesses antimicrobial activity against all 3 pyogenic bacteria and potent as standard 12 antimicrobial drugs. The extracts showed a broad spectrum of antibacterial activity, inhibition zones of bacteria strains ranged from 3-12 mm for Staphylococcus aureus,3-15mm for Streptococcus pyrogens 5-12 mm for E. coli. The result of the study supports the immense medicinal properties of Brassica juncea which has revealed a significant scope to develop a novel broad spectrum of antibacterial herbal formulation. Again Brassica alba was found superior in antibacterial action as compared to Brassica juncea as its mention in Ayurved Lexicon Bhavprakash Nighantu, ${ }^{[3,4]}$ results substantiate the same. This is further open for research workers to carry out further research work on this project and to see the phagocytic action of the drug, fix the dose of the drug, fractionization of water and methanol extracts by HPTLC separation of active principle as further drug development.

Keywords: Brassica juncea, Brassica alba, antibacterials agents, herbal medicine.

\section{INTRODUCTION}

During this Covid-19 Pandemic situation, a renewed interest in improving health and fitness using more natural products. Herbs and spices have been used for thousands of years to enhance the flavour, colour, and aroma of food, also known for their preservative and medicinal value. The success story of chemotherapy lies in the continuous search for new drugs to counter the challenge posed by resistant strains of microorganisms. The investigation of certain indigenous plants for their antimicrobial properties may yield useful results. Many plants indeed were used to combat different diseases and known to possess antimicrobial activity ${ }^{[5]}$. Mustard has been used as medicine over hundreds of years which informed the choice for this study. Mustard seed is widely utilized in the preparation of varieties of edible sauces, pastes and pickles. The number of emerging multidrug-resistant microbial strains is continuously increasing and has become one of the most serious threats to the successful treatment of infectious diseases ${ }^{[6]}$. This increase is mainly attributed to the indiscriminate use of broad-spectrum antibiotics ${ }^{[7,8]}$. In Ayurveda, Mustard oil is used for the treatment of infected wounds as a local application, and Mustard seeds had been used for disinfection, home, hospitals, labour rooms and operation theatres in the form of medicated fumigation which is called Dhoopan.
Brassica junncea and Brassica alba are some of the most popular species of mustard of the family Cruciferae. The world health organization (WHO) reported that about $80 \%$ of the world's population depends primarily on traditional medicine that mainly involves the use of plant extract. This study, therefore, evaluated the efficacy of Brassica juncea (brown mustard) seeds as a potential antimicrobial agent against pathogenic microbes.

\section{Materials and Methods}

\section{Sample collection}

The seeds of Brassica juncea and Brassica alba were cultivated my farms in Washim District, Maharashtra, in June and harvested in the month of March.

\section{Mustard Seeds various Extract preparation}

The extraction reagents were water, Petroleum ether, methanol \& Chloroform. About $10 \mathrm{~g}$ of the mustard seed was placed in a beaker and $25 \mathrm{ml}$ of methanol added and it was frequently shaken for six hours, then it was allowed to stand for $18 \mathrm{hrs}$. Then it was evaporated to $25 \mathrm{ml}$ of volume in a tared flat bottomed shallow dish and was dried at 105 degrees centigrade. The same procedure was repeated for that of methanol \& Chloroform. For Ether soluble extract $50 \mathrm{gm}$ of coarse seed powders of both Brassica species were taken in the round bottom flask,500 $\mathrm{ml}$ of petroleum ether (B.P. 
60-80 degrees Centigrade) was added to it, then it was extracted with Soxhlet apparatus for $6 \mathrm{Hrs}$. Then the filtered and distilled to get dry petroleum ether extract. Preparation of glassware and other types of equipment-

All the apparatus used for the study, such as Petri plates, test tubes, pipettes, conical flasks, cork borers, scalpels, etc were cleaned with soap, rinsed with water, air-dried, wrapped with brown paper and sterilised in a hot oven at 160-degree centigrade for $2 \mathrm{Hrs}$.

\section{Preparation of Media-}

The agar media was already constituted and was directly used. The Agar powder was digested in distilled water, measured volumetrically into dry test tubes, plugged tightly with a cap and sterilised by autoclaving for 20 minutes at a pressure of $15 \mathrm{lbs}$. The sterile media was allowed to cool and form stubs in the test tubes. After storing overnight, the test tubes were examined visually for any signs of microbial growth, and only after confirmation of sterility, the media was melted and poured aseptically into glass Petri plates, to be used for further study and a basal layer was formed.

\section{Preparation of test solution-}

The extracts of seed powder of both species of Brassica were taken by successive solvent extraction methods in the Soxhlet apparatus. The petroleum ether extract was fixed oil, chloroform extract and methanol extract were also oils, only water extract was dissolved in sterile water in 1:5 ratio dilution.

\section{Preparation of standard drug}

The standard drug was bought from the market as Biodisc, Batch No-512BAT165, Code No-4508 from Micro master company.

\section{Details of standard antibiotic}

AN-Amoxycillin 10mcg, AU-Augmentin 30mcg, CXCephotaxime $30 \mathrm{mcg}$, CA-Ceftriaxone $30 \mathrm{mcg}$, CO-
Cefuroxime $30 \mathrm{mcg}$, CP-Ciprofloxacin $5 \mathrm{mcg}$, CYClindamycin 2mcg, ER-Erythromycin $15 \mathrm{mcg}$ G-Gentamycin 15 mcg, L-Lincomycin 2 mcg, OF-Ofloxacin 5mcg, TO-Tobramycin $10 \mathrm{mcg}$

\section{Test Microorganisms- Culture preparation}

$24 \mathrm{Hrs}$ old broth cultures of the following test microorganisms were obtained from the Microbiology dept of Mumbai Veterinary college, Parel Mumbai-12, and was used for the antibacterial study.

1.Streptococcus pyogens

2.Staphylococcus aureus

3.E.coli

\section{Cup Plate technique}

The $24 \mathrm{Hr}$ old broth culture was washed with $5 \mathrm{ml}$ of sterile saline, $0.1 \mathrm{ml}$ of this culture suspension was diluted with $50 \mathrm{ml}$ of sterile saline to give a culture suspension containing $1 \times 106$

Microorganisms $/ \mathrm{ml} .1 \mathrm{ml}$ of this culture suspension was used for inoculation of agar plates.

\section{Method of testing}

Preliminary antibacterial testing was carried out for all extracts of both Brassica species by the Agar plate technique.

\section{Cup Plate technique-}

$15 \mathrm{ml}$ of sterile nutrient agar was poured into sterile Petri plates and allowed to solidify. This formed the basal layer. $1 \mathrm{ml}$ of the inoculum was added to the sterile molten agar at 40 degrees $\mathrm{C}$, mixed well, and poured uniformly onto the basal layer around $15 \mathrm{ml}$ and allowed to solidify. This formed a seed layer. Sterile cork borers were used to bore wells of diameter 1 $\mathrm{mm}$ in the plate. Solution of the extracts was poured into the wells and plates were incubated at 37 degrees $\mathrm{C}$ for $18 \mathrm{Hrs}$. The zone of inhibition against each organism was measured, also for standard drug antibiotics. 


\section{Results}

Table-1: Antibacterial activity of Brassic juncea (Zone of Inhibition in mm by Agar Cup technique) Mean \pm SD

\begin{tabular}{|l|l|l|l|l|l|l|}
\hline Sr. No & $\begin{array}{l}\text { Test microorgan- } \\
\text { ism }\end{array}$ & Crude oil & $\begin{array}{l}\text { Water ex- } \\
\text { tract }\end{array}$ & $\begin{array}{l}\text { Chloroform } \\
\text { extract }\end{array}$ & $\begin{array}{l}\text { Methanol } \\
\text { extract }\end{array}$ & $\begin{array}{l}\text { Petrolieum } \\
\text { ether extract }\end{array}$ \\
\hline 01 & $\begin{array}{l}\text { Streptococcus } \\
\text { pyrogens }\end{array}$ & NZI & $11 \pm 0.84$ & NZI & $15 \pm 0.80$ & NZI \\
\hline 02 & $\begin{array}{l}\text { Staphylococcus } \\
\text { aureus }\end{array}$ & NZI & $12 \pm 0.63$ & NZI & $12 \pm 0.84$ & NZI \\
\hline 03 & E.coli & NZI & $10 \pm 0.85$ & NZI & $14 \pm 0.85$ & NZI \\
\hline
\end{tabular}

Table 2: Antibacterial activity of Brassica alba (Zone of Inhibition in mm by Agar Cup technique) Mean \pm SD

\begin{tabular}{|l|l|l|l|l|l|l|}
\hline Sr. No & $\begin{array}{l}\text { Test microorgan- } \\
\text { ism }\end{array}$ & Crude oil & $\begin{array}{l}\text { Water ex- } \\
\text { tract }\end{array}$ & $\begin{array}{l}\text { Chloroform } \\
\text { extract }\end{array}$ & $\begin{array}{l}\text { Methanol ex- } \\
\text { tract }\end{array}$ & $\begin{array}{l}\text { Petrolieum } \\
\text { ether extract }\end{array}$ \\
\hline 01 & $\begin{array}{l}\text { Streptococcus } \\
\text { pyogens }\end{array}$ & NZI & $12 \pm 0.84$ & NZI & $15 \pm 0.80$ & NZI \\
\hline 02 & $\begin{array}{l}\text { Staphylococcus } \\
\text { aureus }\end{array}$ & NZI & $14 \pm 0.63$ & NZI & $16 \pm 0.84$ & NZI \\
\hline 03 & E.coli & NZI & $11 \pm 0.85$ & NZI & $14 \pm 0.85$ & NZI \\
\hline
\end{tabular}

NZI- No zone of inhibition

\section{DISCUSSION}

In recent years, multiple drug resistance in human pathogenic microorganisms has been developed due to the indiscriminate use of commercial antimicrobial drugs commonly applied in the treatment of microbial infections $[6,7]$. Research over the years has shown that medicinal plants possess in them bioactive components with valuable therapeutic relevance which can be harnessed in alternative medicine for the prevention, treatment and control of antibiotics resistant human pathogens as well as fungi [8]. In this way, though the microbes have been perused since the very earliest in Vedas, a systemic development covering all aspects of the subjects could have been observed during the period of Samhitas in Ayurved. But the surgical branch of Ayurveda, which is mostly dealt with various infectious conditions after surgical procedures, hence elaboratively explained. Rakshasas, Rakshavidhan, Dhoopan, Agnihotras. Ayurvedic concept of Rakshoghna karma is very vast and include preventive, and curative factors against microbial infections and nowadays one can use these Rakshoghna drugs mentioned in Ayurveda texts as preventive measures against conditions such as pandemic situations. But this branch of ancient microbiology rooted in Atharva
Veda remained rudimentary, due to lack of further research and attack of Chemotherapeutic agents. In ancient times, Yagnas, Agnihotras, Dhoopan were used to performed routinely by our Rishis, they were helping to eradicate pollution, attack microbes and maintain atmospheric hygiene, it was recently scientifically proven that Agnihotra destroys gram-positive and gram-negative bacterias. Rakshoghna concept should be studied again elaboratively to find out the authenticity of the fact mentioned in the Ancient literature of Ayurveda.

Pharmacognostical, the organoleptic study revealed out that both the species of Brassica having no such gross difference. In vitro study revealed out that the crude oil of the Brassica juncea and Brassica alba does not show any inhibition zone and is not a potent antibiotic drug against pyogenic bacteria though in Ayurveda texts it has mentioned as a wound healing property especially in infected wounds. Water and Methanol extract of both Brassica species extracts possess significant antibacterial activity.

1.Zone of inhibition for Brassica juncea water extract against pyogenic bacteria showed a range between 10 $12 \mathrm{~mm} \&$ Methanol extract showed zone of inhibition ranged between $12-15 \mathrm{~mm}$, which is significant. 
2. Zone of inhibition for Brassica alba water extract against pyogenic bacteria showed a range between 11 $14 \mathrm{~mm} \&$ Methanol extract showed zone of inhibition ranged between $12-16 \mathrm{~mm}$, which is highly significant. The activity was compared with standard 12 potent chemotherapeutic agents mentioned earlier, out of which Erythromycin and Clindamycin do not possess zone of inhibition against all 3 pyogenic bacteria, while water extract and methanol extract possess significant antibacterial activity against all 3 pyogenic microorganisms, both the Brassica species extracts were as potent as standard 12 chemotherapeutic agents in antibiotics. This study concentrated on pyogenic bacteria and this is further open for research workers to carry out further research work on this project and to see the phagocytic action of the drug, fix the dose of the drug, fractionization of water and methanol extracts by HPTLC, separation of active principle as further drug development and its formulation on the infected wound for disinfecting the wound and wound healing purpose.

\section{CONCLUSION}

From the present study, it can be concluded that the water and methanol extracts of Brassica juncea \& Brassica alba seeds are effective antimicrobial agents against pyogenic bacterias \& microbes. Brassica juncea and Brassica alba are freely available, safe, economic drugs showing potent antimicrobial activity when used as water and methanol extracts, and they can be formulated as medicated dressings for infected wounds for local application. The result of the study supports the immense medicinal properties of both Brassica species seed which has revealed a significant scope to develop a novel broad spectrum of antimicrobial herbal formulation. This study paves the way for further research and development to identify the active compounds responsible for antimicrobial activity in Vitro. Further studies necessary to find out these bioactive components and their exact mechanism of action are highly suggested and recommended.

\section{Acknowledgement}

1.The whole project of Efficacy evaluation of extracts of Brassica juncea and Brassica alba seeds as a potential antibacterial agent, in Vitro, against $\mathbf{P y -}$ ogenic bacteria -Streptococcus Pyogens, Staphylococcus aureus and E.Coli was funded by CCRAS, New Delhi. (2002-2005)

2.Whole in Vitro research work was carried out at Zandu Pharmaceuticals, Prabhadevi, Mumbai

3.Cultures of Microbes were received from Mumbai Veterinary College, Parel, Mumbai-12

\section{REFERENCES}

1. Efficacy evaluation of extracts of Brassica juncea (Brown mustard) seeds as a potential antimicrobial agent against pathogenic microbes Odangowei I Ogidi, Dienize G George, Uchechi E Enenebeaku, Ngozi G Esie and Udeme M Akpan

2. Sushruta Samhita Uttartantra (60/46-53), Chaukhambha Orientalia, Varanasi

3. Bhavprakash Nighantu Dhanyavarga 71, Chaukhambha Visvabharti, Varanasi

4. Bhavprakash Nighantu, Tailvarga 13-14, Chaukhambha Visvabharti, Varanasi

5. Arora DS, Kaur J. Antimicrobial Activities of spices. International Journal of Antimicrobial Agents. 1999; 12: 257.

6. Sharma R, Sharma CL, Kapoor B. Antibacterial resistance: current problems and possible solutions. Indian Journal of Medical Sciences. 2005; 59:120-129.

7. Jadhave VD, Bhanuwanshe SM, Patil SP, Chavshori DV. Antibacterial activity of different plant and callus extract a comparative study. International Journal of scientific and technology research. 2013; 2:2277-8616.

8. Shahidi GH, Bonjar S, Fooladi MH, Mahadevi MJ, Shahghasi A. Broad spectrum, a novel antibacterial from Streptomyces species. Biotechnology. 2004; 3:126-130.

\section{Source of Support: Nil \\ Conflict of Interest: None Declared}

How to cite this URL: Seema Nishant Parma et al: Efficacy Evaluation Of Extracts Of Brassica Juncea And Brassica Alba Seeds As Potential Antibacterial Agent-In Vitro Study, Against Pyogenic Microbes - Streptococcus Pyrogens, StaphyloCoccus Aureus And E.Coli. International Ayurvedic Medical Journal \{online\} 2021 \{cited July 2021\} Available from: http://www.iamj.in/posts/images/upload/1344_1348.pdf 